\title{
Записи предања у Етнографској збирци САНУ у периоду од 1886. до 1914. године
}

\author{
Даница Јовић
}

У раду су представљене идентификација и класификација записа предања из различитих рукописа из Етнографске збирке САНУ. Дат је осврт на оснивање и рад Етнографског одбора САНУ, који је иницирао и подстицао прикупљање „народног блага“ и окупљао многобројне сараднике из редова учитеља, свештеника и ђака. Рашчитане су и прегледане збирке које су у Академију стигле од 1886. до 1914. године, са циљем да се пруже примарни подаци о постојању и врстама предања у рукописима. Предања су класификована према међународној или будимпештанској подели предања, а дат је осврт и на контекст и начин бележења предања.

Кључне речи: Етнографска збирка САНУ, српска народна предања, међународна класификација предања, етнографско бележење предања

Вредност предања у нашој научној средини први је препознао Вук Стефановић Караџић. Добро је познато да је овој усменој врсти Вук место доделио у Животу и обичајима народа српскога (1867), али да их је такође доносио и у збиркама приповедака и народних песама и штампао уз одреднице у Српском рјечнику. Да је инстинктивно умео да препозна вредност и особености фолклорних врста, Вук Караџић је доказао и када је реч о предањима. Бележио их је уз формулне изразе (нпр. „Срби причају“) (Milošević-Đorđević 2012: 10), који потврђују веродостојност исприповеданог и колективна веровања на којима почивају. Вук је предања посматрао пре свега као етнографску грађу, што је делом утицало и на то да она као фолклорна и уметничка врста дуго остану на маргини истраживања. И поред тога, предања су бележена и објављивана у часописима, алманасима, календарима, као етнографска грађа и у склопу монографија. ${ }^{1}$ Предања су и део богате

\footnotetext{
${ }^{1} 0$ проучавању и бележењу предања у српској научној средини в. у: MiloševićĐorđević 2012: 205-210; Милошевић-Ђорђевић 2013: 41-50.
} 
и још недовољно проучене грађе која чини Етнографску збирку САНУ. ${ }^{2}$ Заједно са још три збирке докумената (Стара збирка, Историјска збирка, Оријентална збирка), Етнографска збирка чини изузетно драгоцен корпус грађе Архива САНУ.

\section{Осврт на настанак и историјат Етнографске збирке САНУ}

Настанак и историјат Етнографске збирке везује се за рад Етнографског одсека, односно Етнографског одбора САНУ. На скупу Академије философских наука 1892. године, Стојан Новаковић је поднео предлог да Академија оснује „Зборник или Архив за скупљање и одабирање народних умотворина српских" (Годишњак 1895: 221). Главни циљ Етнографског одсека је био издавање критички уређеног зборника „свега умственог блага народног, у колико га нема у зборницима Вука Ст. Караџића (Годишњак 1895: 221-222). За првог редактора зборника постављен је Пера П. Ђорђевић 1894. године. Прикупљање народних умотворина Етнографски одбор је видео као први корак у остваривању важнијег циља Академије, а то је уређење и објављивање „једног великог Зборника, у који би ушле, критички одабране, хронолошки, географски и стручно распоређене, како све оне народне умотворине које су - изван велике збирке Вукове - до сад већ било где објављене (у многобројним посебним издањима и у многим књижевним листовима, календарима, алманасима, забавницима), тако и све оне које би се међу овим послатим рукописним збиркама пронашле као нове, нигде раније нештампане или као варијанти, достојни да стану напоредо са својим прегледалицама“ (Годишњак 1895: 223-224). Задатак Одбора је био да прегледа и пронађе сва

\footnotetext{
${ }^{2}$ Етнографска збирка чува се у Архиву Српске академије наука и уметности. Почетак рада Архива везује за 1841. годину и оснивање Друштва српске словесности, које се бавило прикупљањем и чувањем грађе за српску историју. Након што је Јован Стејић изложио идеју о сакупљању докумената из Првог српског устанка, а Аврам Петронијевић изнео план о прикупљању грађе, Друштво је 1846. године почело с интензивним радом, посвећујући пажњу и „српском језику, старим српским обичајима, песмама и предањима“ (Ђорђевић 1984: 11), и од тада почиње сакупљање различите историјске, етнографске, културне и друге грађе. На скупу који је одржан 4. октобра 1899. године, Председништво Академије је покренуло идеју о уређивању Академијине Историјске збирке и Архива, као и о томе да поменута грађа постане доступна научној јавности. Архив Српске краљевске академије је формиран исте године, али је јавности постао доступан тек 1952. године, када је прешао из Бранкове улице у данашњу зграду САНУ у Кнез Михаиловој улици. 0 Архиву САНУ в. и: Ђорђевић 2010: 17-18.
} 
она издања у којима су народне умотворине објављиване, затим да систематизује постојећу грађу (исписивањем сажетка сваке умотворине), упореди је са оном већ објављеном у делима Вука С. Караџића; напослетку, да одабере оно што је вредно да се објави у Академијином зборнику (Годишњак 1895: 224-225).

Замисао о издавању Зборника подстакла је Милана Ђ. Милићевића да опише народни живот и обичаје „Срба сељака“. Академија је тај рад објавила 1894. године као прву књигу у серији Српског етнографског зборника, а убрзо потом изашла је и друга књига Српског етнографског зборника под називом Старинска српска јела и пића Симе Тројановића (1896). У Етнографској збирци САНУ под сигнатуром ЕЗ 378/1 и 381/2 налази се и штампани позив Југославенске академије знаности и уметности из 1895. године за прикупљање грађе за издавање зборника фолклорне грађе. ${ }^{3}$

Већ у првим годинама рада у Академију је стигла обимна грађа, па је 1898. одлучено „да се посао о прикупљању грађе за Етнографски зборник повери нарочитом одбору“ (Годишњак 1898: 49). Тада су изабрани и први чланови одбора: Јован Мишковић као председник (наредне године га је заменио Михаило Валтровић), Љубомир Ковачевић, Љубомир Јовановић, Љубомир Стојановић, Пера П. Ђорђевић. Наредних година у Одбор улазе и Јован Цвијић, Сима Тројановић, Александар Белић, Јован Ердељановић, Стеван С. Мокрањац, Милан Јовановић Батут, Станоје Станојевић и др. Када је на седници Академије 1898. године донета одлука о оснивању Одбора, утврђени су и критеријуми за прикупљање грађе: „Одбор је сачинио и нарочит начин шта би требало прикупљати и упутства по којима би сакупљачи радили“, скрећући пажњу на Вукове збирке и на две објављене књиге Академије (Милићевићеву и Тројановићеву), „па и на оне које ће од сада излазити, те да свак у свом крају види шта је друкчије, потпуније, познато или непознато од онога што је већ у [...] књигама објављено“.

Етнографски одбор се залагао за систематично прикупљање и објављивање грађе из народног живота. У збирци Е3 378 (Неке расуте хартије Етнографског одбора) налази се и спис: Предлог за организовање рада на проучавању народног живота и обичаја и о начину издавања грађе и расправа те врсте у Академији Наука. Једна од првих одлука која је овде донета тиче се штампања Упутстава за проучавање народног живота и обичаја. Предложено је да се за основу узму упутства Јована

\footnotetext{
${ }^{3}$ Позив је штампан у 15. свесци Рјечника хрватскога или српскога језика, издатој у Загребу 1895. године. В.: Архив Српске академије наука и уметности (даље: Архив САНУ), фонд Етнографске збирке (даље ЕЗ), 378/1 и 378/2.

${ }^{4}$ Записано на седници Академије од 15. јула 1898 године, Архив САНУ, Е3, 376/2.
} 
Ердељановића које је штампала Академија, изоставе они делови којих има код Цвијића и допуне према упутствима Тихомира Ђорђевића. Упутства би требало „разаслати свим интелигентнијим људима у народу“, с нагласком „да је најбоље проучити щео народни живот“ у неком крају, али и допустити „да се добро проучи ма и само једна страна народног живота“. ${ }^{5}$ Од сакупљача се тражило да у прикупљеној грађи да што вернију слику народног живота, а од уредника да грађу задржи без одабирања и одбацивања, као и да не штампа већ објављену грађу. У истом спису налази се и део упутстава за прикупљање грађе. ${ }^{6}$

Део богате грађе која спада у Етнографску збирку објављиван је у четири серије Српског етнографског зборника. Српски етнографски зборник је почео да излази 1894. године (прва књига је била друго допуњено и прерађено издање Милићевићеве књиге Живот Срба сељака), а с временом су се у склопу едиције издвојила четири одељења: Насеља српских земља, које је од 1921. преименовано у Насеља и порекло становништва; Живот и обичаји народни, Српске народне умотворине и Расправе и грађа. Иницијалну идеју о објављивању народних умотворина доследно је спровео Веселин Чајкановић. У оквиру едиције Српске народне умотворине, 1927. године објављена је збирка Српске народне приповетке, која представља критички избор текстова из рукописне грађе Етнографске збирке.

У периоду након Другог светског рата, Етнографски одбор и његов рад на објављивању Етнографске збирке пролазио је кроз различите фазе (в.: Младеновић 2005). Етнографску збирку је након Одбора за народне умотворине Етнографског института преузео Архив САНУ 1975. године.

У Архиву САНУ налазе се обједињене две књиге сумарног Инвентара Етнографске збирке. У првој књизи Инвентара Етнографске збирке налазе се рукописи од редног броја 1 до броја 438, а у другој рукописи од редног броја 439, који су примљени од 1974. или су накнадно пронађени у Архиву. Према записнику од 10. јула 1974. године, када су извршене ревизија и примопредаја Етнографске збирке, утврђен је тачан број инвентарских јединица. Према овој ревизији, поједине збирке су враћене ауторима (бр. 128, 198, 385, 386; 229, 312, 313, 330, 354); одређени бројеви предати су Институту за српски језик или пребачени у Библиотеку САНУ; а неке збирке нису пронађене (бр. 80, 115, 116,

\footnotetext{
${ }^{5}$ В.: Архив САНУ, ЕЗ 378/1 и 378/2

${ }^{6}$ Хартије су расуте и непотпуне, није јасно да ли је реч о записнику са седнице Одбора. Није наведена ни година када је спис настао, али на основу тога што се у спису спомиње да је Етнографски одбор штампао XXII књигу Зборника, може се претпоставити да то није могло бити пре 1921. године.
} 
$169,332-339,318,380,382,392,398,406)$. Подаци које нам пружа Инвентар Етнографске збирке односе се на: редни број збирке; презиме, име и занимање сакупљача; место настанка збирке; назив списа; сумарни садржај (број умотворина пронађених у рукописима); број свезака за сваку инвентарску јединицу и број кутије у којој се налази; датум примања рукописа; награду која је издата сакупљачу; напомену о рукопису. Напомене у Инвентару доносе посебно вредне податке о томе да ли су рукописи штампани и, ако јесу, у којој књизи Српског етнографског зборника; да ли је рукопис враћен сакупљачу, предат некој научној институцији или појединцу. У напоменама су и подаци о томе од кога су умотворине забележене, тумач непознатих речи и сл. Поменуто је да је целовитост Етнографске збирке нарушена одливом (поједине збирке враћене су сакупљачима, послате Институту за српски језик и Библиотеци САНУ), али и немаром: један део збирки је, након штампања, остајао у штампарији и никад није враћен у Архив, док се за неке од кутија у којима су били рукописи не зна шта се догодило.

У фонду Етнографске збирке, најстарији рукописи су збирке Вука Врчевића (рукопис пословица из 1868, те књиге песама добијене од Библиотеке Српског ученог друштва), Богољуба Петрановића (књиге песама добијене од Библиотеке Српског ученог друштва) и збирка из рукописне заоставштине Владана Арсенијевића из Делиблата, 1865-1882 (Гароња-Радованац 2012: 206). Из Инвентара се види да су најстарији рукописи Одбору стигли 1886. године (збирке Васе Ћуковића из Сарајева и Николе Кукића, питомца манастира Гомирја), а последње збирке 1980. године.

Књига инвентара Етнографске збирке доноси за највећи број рукописа прецизне податке о сакупљачима и месту настанка. Збирке су стизале од свештеника, учитеља, студената, ђака, управитеља школа, писара и професора, из различитих делова Балканског полуострва. Неки од сакупљача који су својим радом посебно обогатили Етнографску збирку су: Јован Л. Срећковић (учитељ из Левча), Тодор Бушетић (учитељ из Левча), Станоје Мијатовић (учитељ), Манојло Бубало Кордунаш (школски надзорник), Мићун Павићевић (књижевник), Петар Мирковић (учитељ у Зеници), Јеремија Павловић (учитељ у Блазнави), Јован Мутић (Босна). У фонду Етнографске збирке налазе се и заоставштине Веселина Чајкановића, Јована Ердељановића и других. На предлог академика Наде Милошевић-Ђорђевић, као приоритетан задатак Одбора за народне умотворине, започет је процес дигитализације Етнографске збирке. Скениране су збирке од броја 1 до броја 56, затим 61-1, као и збирка под редним бр. $211 .^{7}$

\footnotetext{
${ }^{7}$ Дигитализација Етнографске збирке поверена је инжењеру Браниславу Томићу.
} 


\section{Записи предања у рукописима Етнографске збирке САНУ од 1886. до 1914. године}

У збиркама које су стизале Етнографском одбору од 1886. до 1914. године срећу се записи различитих врста предања. Ради прегледности, предања су представљена у Табели $1,{ }^{8}$ заједно с подацима о прикупљеним предањима. Рубрике садрже:

1. редни број збирке у којој се налази предање;

2. име, презиме и занимање сакупљача (творца збирке); 9

3. назив збирке и време када је доспела у Архив;

4. наслов рукописа или наслов предања у збирци (ако наслов не постоји, узимане су почетне речи); број сигнатуре, ако су листови у збирци сигнирани, односно број стране или редни број умотворине под којом се предање налази ако сигнатуре нема;

5. коментар - у овој рубрици доносимо напомене о врсти предања, као и о контаминацији жанра предања с другим сродним врстама.

Предања су разврстана тематски, у складу с међународном или будимпештанском поделом предања на етиолошка и есхатолошка, културноисторијска, митолошка и демонолошка, и легенде ${ }^{10}$ (в.: Bošković-Stulli 1968; Милошевић-Ђорђевић 2006, 2013). Међународни критеријуми у подели предања прихваћени су и у нашој научној средини, уз одређена одступања и прилагођавања конкретној грађи која се проучава. Ослањајући се на тематски критеријум, сакупљачи и проучаваоци (в.: Ђорђевић 1988, Марковић 2004) указивали су и на одређене подврсте предања (в.: Karanović 1989, Палавестра 2003). Сматрали смо да је тематска класификација примењива када се ради о сложеном корпусу грађе у Етнографској збирци јер нам пружа приближно тачан увид у заступљеност различитих врста предања, њихово међусобно прожимање и прожимање с фолклорним врстама, пре свега легендама. Месна предања и предања о насељавању становништва такође су део Етнографске збирке.

\footnotetext{
${ }^{8}$ Из прегледа су изостала предања из збирке Симе Ђурића-Јовановића из 1887. године из Горње Крајине, коју нисмо успели да рашчитамо за ову прилику. За све остале збирке пристигле у периоду од 1886. до 1914. настојали смо да утврдимо да ли у њима постоје предања и у ком облику.

${ }^{9}$ Подаци о сакупљачима и збиркама (време, место и назив) донети су на основу информација које стоје уз сваки од рукописа Етнографске збирке САНУ.

${ }^{10}$ Термин 'легенда' користи се у српској фолклористици у више значења, а једним делом се преклапа с термином 'легендарна прича', в.: Милошевић-Ђорђевић 2006.
} 
Имајући науму да „више од осталих прозних врста, предања пружају отпор сваком типологизирању“ (Милошевић-Ђорђевић 2006: 173), понуђена класификација је сачињена с намером да се пруже само примарне информације о жанру, као и тематици предања и комуникативној форми где смо сматрали да потребно. Детаљније проучавање жанровских особености издвојене грађе захтевало би посебну студију која би подразумевала и дубље улажење у сложен однос међужанровских прожимања, питања контекста и текста, као и односа сакупљача/записивача према усменом делу и његових интервенција у тексту.

\section{Табела 1}

\begin{tabular}{|c|c|c|c|c|c|}
\hline \multicolumn{6}{|c|}{ Записи предања у рукописима Етнографске збирке САНУ од 1886. до 1914. године } \\
\hline $\begin{array}{l}\text { РЕД- } \\
\text { НИ } \\
\text { БРОЈ }\end{array}$ & $\begin{array}{l}\text { ИМЕ } \\
\text { САКУПљАЧА }\end{array}$ & MECTO & $\begin{array}{l}\text { НАЗИВ РУКО- } \\
\text { ПИСА И ВРЕМЕ } \\
\text { СЛАЬА }\end{array}$ & $\begin{array}{l}\text { НАСЛОВ рукописа/ записа; } \\
\text { сигнатура, тј. број стране или } \\
\text { редни број предања у збирци }\end{array}$ & $\begin{array}{l}\text { Коментар } \\
\text { (контекст } \\
\text { бележења, } \\
\text { врста предања, } \\
\text { развијеност об- } \\
\text { лика) }\end{array}$ \\
\hline 1. & $\begin{array}{l}\text { Јован Л. } \\
\text { Срећковић }\end{array}$ & Левач & $\begin{array}{l}\text { Српске народне } \\
\text { приповетке } \\
1890-1894 . \\
1894 . \\
1897 .\end{array}$ & $\begin{array}{l}\text { Како је остало да се отац и } \\
\text { мати поштују 1_2_4 } \\
\text { Зашто село Топола у срезу } \\
\text { беличком има само седам кућа } \\
\text { 1_2_7 } \\
\text { Вампир и вампирче 1_2_4 } \\
\text { Како је постала мечка 1_2_17а }\end{array}$ & $\begin{array}{l}\text { Етиолошко } \\
\text { предање } \\
\text { Етиолошко } \\
\text { предање } \\
\\
\text { Демонолошко } \\
\text { предање } \\
\text { Етиолошко } \\
\text { предање }\end{array}$ \\
\hline 4. & $\begin{array}{l}\text { Никола } \\
\text { Јакшевац, } \\
\text { гимназијски } \\
\text { предавач }\end{array}$ & $\begin{array}{l}\text { Округ } \\
\text { пиротски и } \\
\text { врањски }\end{array}$ & $\begin{array}{l}\text { Приповетке из } \\
\text { Пиротског и } \\
\text { Нишавског сре- } \\
\text { за и Врањског } \\
\text { округа (Дода- } \\
\text { так: Приповетке } \\
\text { из Врањског } \\
\text { округа). } \\
1892 .\end{array}$ & $\begin{array}{l}\text { Човек и кума му ала 4_3_01 } \\
\text { Таласам и воденичари 4_3_04a } \\
\text { Три кукавице 4_3_12а } \\
\text { Зашто се преко великог поста } \\
\text { риба не једе 4_3_25. } \\
\text { Бог је човека осудио да пати } \\
\text { зарад једног човека, из Врања } \\
\text { 4_3_38 }\end{array}$ & $\begin{array}{l}\text { Демонолошко } \\
\text { предање } \\
\text { Демонолошко } \\
\text { предање } \\
\\
\text { Демонолошко } \\
\text { предање } \\
\text { Етиолошко } \\
\text { предање } \\
\text { Етиолошко } \\
\text { предање }\end{array}$ \\
\hline
\end{tabular}




\begin{tabular}{|c|c|c|c|c|c|}
\hline 5 & $\begin{array}{l}\text { Драгутин } \\
\text { Костић, про- } \\
\text { фесор }\end{array}$ & $\begin{array}{l}\text { Београд- } \\
\text { ска око- } \\
\text { лина }\end{array}$ & $\begin{array}{l}\text { Српске народне } \\
\text { приповетке } \\
1892 .\end{array}$ & Како су се разделили језищи 5_2 & $\begin{array}{l}\text { Етиолошко } \\
\text { предање }\end{array}$ \\
\hline 16 & $\begin{array}{l}\text { Марић Светис- } \\
\text { лав, учитељ }\end{array}$ & Заплање & $\begin{array}{l}\text { Приче } \\
1897 .\end{array}$ & $\begin{array}{l}\text { Бог и човек 16_5 } \\
\text { Свети Сава 16_5 } \\
\text { Север и југ 16_5 }\end{array}$ & \begin{tabular}{|l} 
Етиолошко \\
предање \\
Легендарна \\
прича с \\
елементима \\
етиолошког \\
предања \\
Етиолошко \\
предање
\end{tabular} \\
\hline 39 & $\begin{array}{l}\text { Тодор М. } \\
\text { Бушетић, } \\
\text { учитељу } \\
\text { Пољни } \\
\text { (Срез левачки, } \\
\text { Округ морав- } \\
\text { ски) }\end{array}$ & Левач & $\begin{array}{l}\text { Приче у Срба } \\
\text { сељака у Левчу } \\
1899 .\end{array}$ & $\begin{array}{l}\text { Свети Никола 39_1_1 } \\
\text { Свети Сава 39_1_1а } \\
\text { Свети Јован 3латоуст } \\
\text { 39_1_1а } \\
\text { Завоји 39_1_5 } \\
\text { Зашто врба роднема 39_1_6а } \\
\text { Вук 39_1_8 } \\
\text { Жаба 39_1_8 } \\
\text { Магарац 39_1_8а } \\
\text { Хајдук 39_1_8а }\end{array}$ & $\begin{array}{l}\text { Легендарна } \\
\text { прича } \\
\text { Легендарна } \\
\text { прича } \\
\text { Две легенде } \\
\text { с елементима } \\
\text { етиолошког } \\
\text { предања } \\
\text { Етиолошко } \\
\text { предање } \\
\text { Етиолошко } \\
\text { предање } \\
\text { Етиолошко } \\
\text { предање } \\
\text { Етиолошко } \\
\text { предање } \\
\text { Етиолошко } \\
\text { предање } \\
\text { Етиолошко } \\
\text { предање }\end{array}$ \\
\hline 53 & \begin{tabular}{|l} 
Петар \\
Мирковић
\end{tabular} & Босна & $\begin{array}{l}\text { Народне припо- } \\
\text { ветке (из Босне) }\end{array}$ & Млинар и виле & $\begin{array}{l}\text { Демонолошко } \\
\text { предање }\end{array}$ \\
\hline
\end{tabular}




\begin{tabular}{|c|c|c|c|c|c|}
\hline 70 & $\begin{array}{l}\text { Тодор М. } \\
\text { Бушетић, } \\
\text { учитељу } \\
\text { Пољни }\end{array}$ & Левач & $\begin{array}{l}\text { Приповетке } \\
1901 .\end{array}$ & 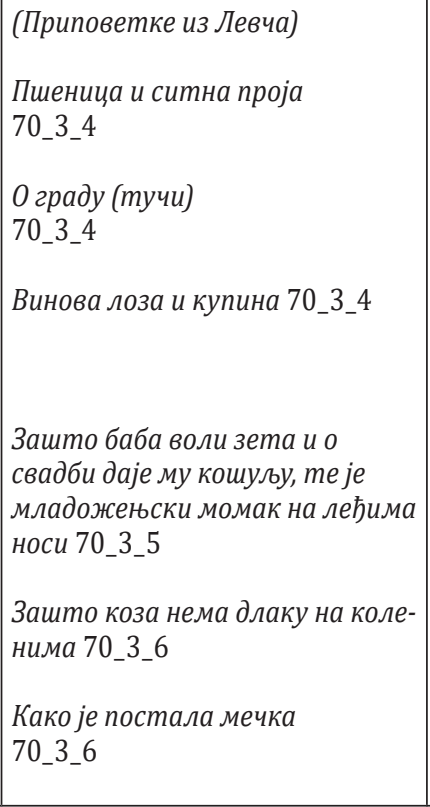 & $\begin{array}{l}\text { Етиолошко } \\
\text { предање } \\
\text { Легендарна } \\
\text { прича } \\
\text { Легендарна при- } \\
\text { ча, етиолошко } \\
\text { предање } \\
\text { Етиолошко } \\
\text { предање } \\
\\
\text { Етиолошко } \\
\text { предање } \\
\text { Легендарна при- } \\
\text { ча, етиолошко } \\
\text { предање }\end{array}$ \\
\hline 74 & $\begin{array}{l}\text { Симо } \\
\text { Милеуснић }\end{array}$ & & & Како је постао обад & $\begin{array}{l}\text { Етиолошко } \\
\text { предање }\end{array}$ \\
\hline 78 & Јован П. Мутић & $\begin{array}{l}\text { Херцего- } \\
\text { вина }\end{array}$ & $\begin{array}{l}\text { Српске народне } \\
\text { приповијетке, у } \\
\text { III и IV свесци, } \\
\text { 1899. и } 1901 .\end{array}$ & $\begin{array}{l}\text { Високи Стеван } \\
78 \_3 \_2 \\
\text { Богати Јов } \\
\text { 78_3_1 } \\
\text { Како је Марко Краљевић посто } \\
\text { јунаком и добио свог Шарца } \\
\text { 78_3_2 } \\
\text { Марко Краљевић у пећини } \\
\text { 78_3_4 } \\
\text { Милош Обилић познаје мајку } \\
\text { 78_3_4 }\end{array}$ & $\begin{array}{l}\text { Културно- } \\
\text { историјско } \\
\text { предање с } \\
\text { елементима } \\
\text { легендарне } \\
\text { приче } \\
\text { Легендарна } \\
\text { прича } \\
\text { Културно- } \\
\text { историјско } \\
\text { предање } \\
\text { Културно- } \\
\text { историјско } \\
\text { предање } \\
\text { Културно- } \\
\text { историјско } \\
\text { предање }\end{array}$ \\
\hline $83 a$ & $\begin{array}{l}\text { Михајло } \\
\text { Ризнић }\end{array}$ & & $\begin{array}{l}\text { Српске народне } \\
\text { приповетке } \\
\text { из Источних } \\
\text { крајева Србије }\end{array}$ & Ала & $\begin{array}{l}\text { Демонолошко } \\
\text { предање }\end{array}$ \\
\hline
\end{tabular}




\begin{tabular}{|c|c|c|c|c|c|}
\hline 103 & $\begin{array}{l}\text { Јован } \\
\text { Воркапић, } \\
\text { свештеник }\end{array}$ & $\begin{array}{l}\text { Банија } \\
\text { (Глина и } \\
\text { Петриња) }\end{array}$ & $\begin{array}{l}\text { Српске народне } \\
\text { приповјетке (са } \\
\text { „примедбама и } \\
\text { разјашњењима“) } \\
1903\end{array}$ & $\begin{array}{l}\text { Најбоље је што Бог чини } \\
\text { 103_30 } \\
\text { Свети Сава и гробар } \\
\text { 103_138 } \\
\text { Камен не расте 103_234 }\end{array}$ & $\begin{array}{l}\text { Легендарна } \\
\text { прича } \\
\text { Легендарна } \\
\text { прича } \\
\text { Етиолошко } \\
\text { предање }\end{array}$ \\
\hline 117 & $\begin{array}{l}\text { Стојан } \\
\text { Дамјановић, } \\
\text { учитељу } \\
\text { Ђевђелији }\end{array}$ & $\begin{array}{l}\text { Маћедо- } \\
\text { нија } \\
\text { (јужна) }\end{array}$ & $\begin{array}{l}\text { Македонске ис- } \\
\text { крице } \\
1903 .\end{array}$ & $\begin{array}{l}\text { Краљевић Марко као } \\
\text { исцелитељ 117_2_55 } \\
\text { Јужна граница краља Вукашина } \\
\text { 117_2_62 }\end{array}$ & \begin{tabular}{|l} 
Културно- \\
историјско \\
предање \\
Културно- \\
историјско \\
предање \\
\end{tabular} \\
\hline 118 & $\begin{array}{l}\text { Ђорђевић } \\
\text { Јанко, учитељ } \\
\text { у Севцу }\end{array}$ & $\begin{array}{l}\text { Сирини-ћка } \\
\text { Жупа }\end{array}$ & $\begin{array}{l}\text { Три народна } \\
\text { предања и } \\
\text { кратак опис } \\
\text { села Севца и } \\
\text { Врбештице у } \\
\text { Сиринићкој } \\
\text { жупи }\end{array}$ & $\begin{array}{l}\text { Постанак ракије } \\
\text { 118_2 } \\
\text { Народно предање о Св. Илији } \\
\text { Постанак села Мужљљака, } \\
\text { Љутоглава и Цапарца 118_2_4 }\end{array}$ & \begin{tabular}{|l} 
Етиолошко \\
предање \\
Легендарна \\
прича \\
Етиолошко \\
предање \\
\end{tabular} \\
\hline 124 & $\begin{array}{l}\text { Симо Ђурић- } \\
\text { Јовановић, } \\
\text { самоук }\end{array}$ & $\begin{array}{l}\text { Горња } \\
\text { Крајина }\end{array}$ & $\begin{array}{l}\text { Народне припо- } \\
\text { ветке из Горње } \\
\text { Крајине } 1887 .\end{array}$ & Од шта су постале виле & \begin{tabular}{|l} 
Нерашчитано, \\
оштећена \\
хартија \\
Више предања \\
\end{tabular} \\
\hline 134 & \begin{tabular}{|l} 
Милош \\
Ивковић, \\
студент \\
философије
\end{tabular} & Ресава & $\begin{array}{l}\text { 1. Народне } \\
\text { приче } \\
1906 .\end{array}$ & $\begin{array}{l}\text { О женидби Краљевића Марка } \\
\text { 134_1_1 } \\
\\
\text { Цар, његов брат и света Петка } \\
\text { 134_1_11 } \\
\text { Свети Јован и девојка } \\
\text { 134_1_13 } \\
\text { Богородица и ђаво } \\
\text { 134_1_35 }\end{array}$ & $\begin{array}{l}\text { Културно- } \\
\text { историјско } \\
\text { предање с еле- } \\
\text { ментима есхато- } \\
\text { лошког предања } \\
\text { Легендарне } \\
\text { приче }\end{array}$ \\
\hline 149 & $\begin{array}{l}\text { Тодор М. } \\
\text { Бушетић }\end{array}$ & Левач & $\begin{array}{l}\text { Народна } \\
\text { предања }\end{array}$ & $\begin{array}{l}\text { Народна предања. Прилог } \\
\text { Историји ослобођења Србије } \\
\text { 149_2 }\end{array}$ & $\begin{array}{l}\text { Више културно- } \\
\text { историјских } \\
\text { предања }\end{array}$ \\
\hline
\end{tabular}




\begin{tabular}{|c|c|c|c|c|c|}
\hline 157 & $\begin{array}{l}\text { Станоје М. } \\
\text { Мијатовић, } \\
\text { учитељ }\end{array}$ & $\begin{array}{l}\text { Левач и } \\
\text { Темнић }\end{array}$ & $\begin{array}{l}\text { Приповетке, } \\
\text { басне, бајке } \\
1908 .\end{array}$ & $\begin{array}{l}\text { 6. Орао и врана } \\
\text { 8. Крт и ћукавац } \\
\text { 10. Свети Сава и ђаво } \\
\text { 11. Ласта } \\
\text { 13. Свети Сава, ђаво и бели лук } \\
\text { 16. Свети Сава и калуђери } \\
\text { 17. Бог и анђео } \\
\text { 20. Свеци на скупу } \\
\text { 23. Христос и бабица } \\
\text { 26. Звао Бога на славу } \\
\text { 27. Старинска заклетва } \\
\text { 30. Свети Сава и богаташ (или } \\
\text { како је постала мечка) } \\
\text { 31. Шура Миливоје } \\
\text { 28. Жељка (корњача) }\end{array}$ & $\begin{array}{l}\text { Етиолошко } \\
\text { предање } \\
\text { Етиолошко } \\
\text { предање } \\
\text { Легендарна } \\
\text { прича с елемен- } \\
\text { тима етиолошког } \\
\text { предања } \\
\text { Етиолошко } \\
\text { предање } \\
\text { Легендарна } \\
\text { прича с елемен- } \\
\text { тима етиолошког } \\
\text { предања } \\
\text { Легендарне } \\
\text { приче } \\
\\
\text { Легендарна } \\
\text { прича с елемен- } \\
\text { тима етиолошког } \\
\text { предања } \\
\text { Легендарне } \\
\text { приче } \\
\text { Етиолошка } \\
\text { предања } \\
\text { Анегдота с еле- } \\
\text { ментима етио- } \\
\text { лошког предања } \\
\end{array}$ \\
\hline
\end{tabular}




\begin{tabular}{|c|c|c|c|c|c|}
\hline & & & & $\begin{array}{l}\text { Додатак: 32? Исус Христосу } \\
\text { народном предању ( о Марији } \\
\text { и како су је гонили): 1. Бог } \\
\text { створио сина да узме тело од } \\
\text { ђавола; } 2 . \text { о томе како је Бог } \\
\text { проклео остургу и јасику; } 3 . \\
\text { како су настале буве; } 4 . \text { Зашто } \\
\text { Јевреји и данас на одређени } \\
\text { празник буше вилама; 5. За- } \\
\text { што се боје јаја; 6. Бог је благо- } \\
\text { словио да се и данас загрће } \\
\text { лонац; 7. Бог је } \\
\text { благословио жабу да се не } \\
\text { црвља; } 8 . \text { Кад је ован с ражња } \\
\text { оживео и заблејао, и петао за- } \\
\text { кукурекао и искочио из лонца, } \\
\text { и Христос је оживео; } 9 . \text { Камен } \\
\text { с Христовог гроба и даље } \\
\text { стоји на истом месту; } 10 . \text { Кад } \\
\text { је Христос васкрсао и победио } \\
\text { ђавола, и отео му људско } \\
\text { тело, ђаво му откинуо комад } \\
\text { меса с ноге, зато људи имају } \\
\text { удубљење на табану; } 11 . \text { Како } \\
\text { су настала брда и планине } \\
\text { (пошла земља за Христом кад } \\
\text { се узносио на небо); } 12 . \text { Кад } \\
\text { је Христос обилазио грешне } \\
\text { душе; 13. Зашто људи више не } \\
\text { знају дан своје смрти. } \\
\text { 43. Зашто Цигани просе? } \\
\text { Човечији живот. }\end{array}$ & $\begin{array}{l}\text { Легендарна } \\
\text { прича с елемен- } \\
\text { тима етиолошког } \\
\text { предања } \\
\\
\text { Етиолошко } \\
\text { предање } \\
\end{array}$ \\
\hline 170 & $\begin{array}{l}\text { Тодор М. } \\
\text { Бушетић }\end{array}$ & Ресава & $\begin{array}{l}\text { Народна } \\
\text { предања у } \\
\text { Ресави }\end{array}$ & $\begin{array}{l}\text { Народна предања у Ресави } \\
170 \_1 \_1 \\
\text { Ресава. С погледом на } \\
\text { дијалекат } \\
170 \_2 \_1 \\
\end{array}$ & $\begin{array}{l}\text { Културно- } \\
\text { историјска } \\
\text { предања }\end{array}$ \\
\hline 182 & \begin{tabular}{|l} 
Дена \\
Дебељковић, \\
свештеник \\
\end{tabular} & Косово & $\begin{array}{l}\text { Приче о Косов- } \\
\text { ском боју } \\
1910 \\
\end{array}$ & Прича о Боју Косовском 182_1 & $\begin{array}{l}\text { Културно- } \\
\text { историјска } \\
\text { предања } \\
\end{array}$ \\
\hline 200 & $\begin{array}{l}\text { Милан Матић, } \\
\text { учитељ у Риб- } \\
\text { нику } \\
\text { (Округ круше- } \\
\text { вачки) }\end{array}$ & $\begin{array}{l}\text { Крушева- } \\
\text { чка жупа, } \\
\text { Копаоник, } \\
\text { итд. }\end{array}$ & $\begin{array}{l}\text { Народ и народ- } \\
\text { ни живот } \\
\text { (оригинални ру- } \\
\text { копис са исправ- } \\
\text { кама и допунама } \\
\text { од уредника Јов. } \\
\text { Ердељановића и } \\
\text { откуцано на пис. } \\
\text { машини) }\end{array}$ & Народ и народни живот & $\begin{array}{l}\text { Више културно- } \\
\text { историјских } \\
\text { предања }\end{array}$ \\
\hline
\end{tabular}




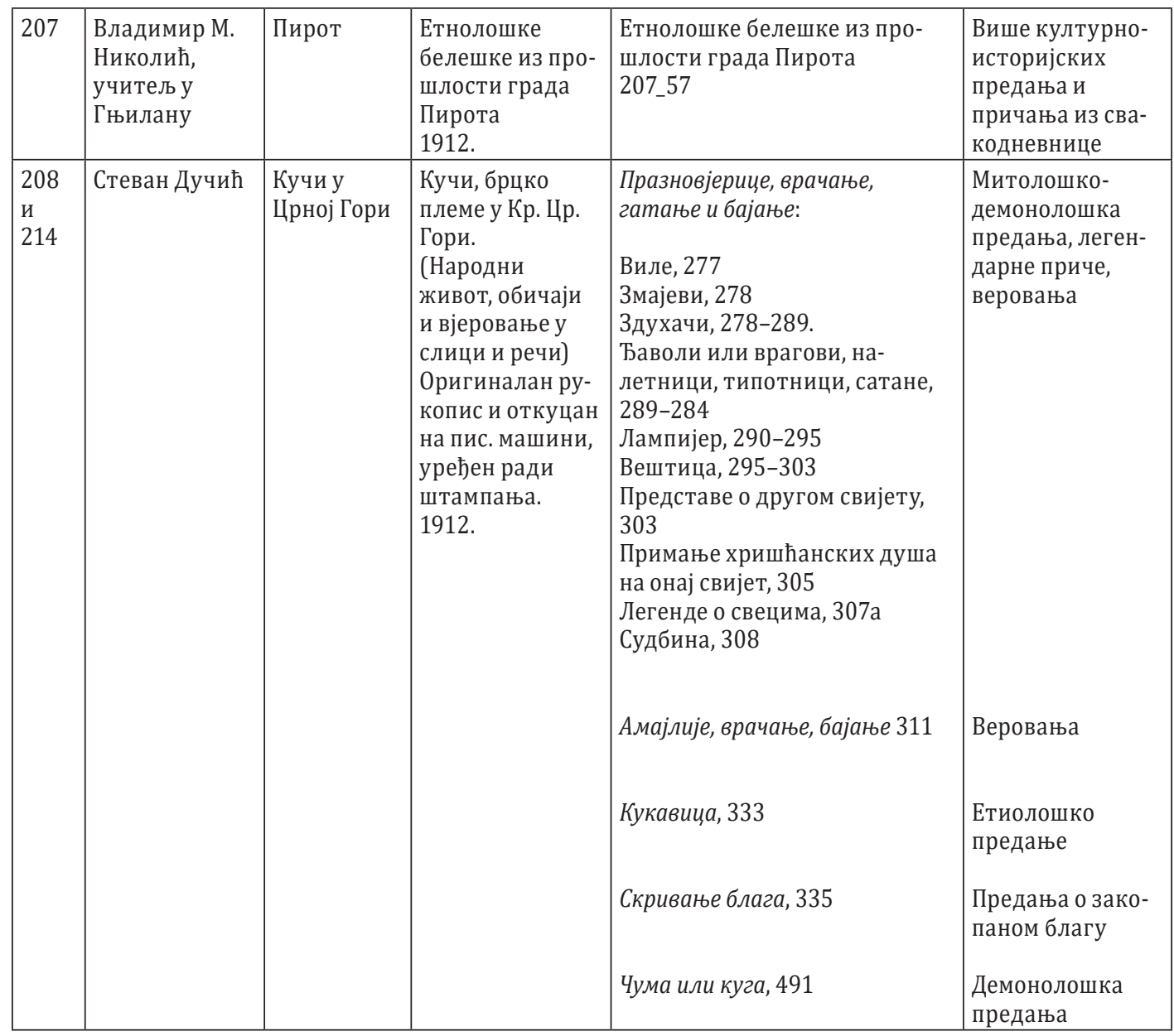




\begin{tabular}{|c|c|c|c|c|c|}
\hline 210 & $\begin{array}{l}\text { Крста } \\
\text { Божовић, } \\
\text { учитељ }\end{array}$ & $\begin{array}{l}\text { Жупа } \\
\text { алексан- } \\
\text { дровачка }\end{array}$ & $\begin{array}{l}\text { Омање народне } \\
\text { приче } 1912 .\end{array}$ & $\begin{array}{l}\text { 12. Што је за једног срећа не } \\
\text { мора бити и за другог } \\
\text { 13. Бојаииска вест } \\
\text { 15. Правда побеђује } \\
\text { 48. Вреле вериге као заклетва } \\
\text { 49. Сада је лето топлије а зима } \\
\text { хладнија но пре } \\
\text { 63. Човек на Бавољој свадби } \\
\text { 64. То исто, мало другаче } \\
\text { 67. Вештица } \\
\text { 241. Хтео ђаво да потоми кола } \\
\\
\text { 270. Воли мушку децу него жен- } \\
\text { ску децу } \\
\text { 287. Бог чува онога кога људи } \\
\text { мрзе } \\
\text { 324. Борба са ђаволима } \\
\text { 326. Анђео узео човеку душу } \\
\text { 329. Потукла их чума због } \\
\text { свађе } \\
\text { 332. Бог не воли ругалице } \\
\text { 396. Умрла у гробљу од страха } \\
\text { 563. Појела вештица деиу } \\
\text { 569. Краљевић Марко видео } \\
\text { пушку први пут } \\
\text { 570. Краљева стопа } \\
\text { 688. Ђаво претворен у чичицу }\end{array}$ & \begin{tabular}{|l} 
Легендарна \\
прича \\
Етиолошко \\
предање \\
Демонолошко \\
предање \\
Етиолошко \\
предање \\
Етиолошко \\
предање \\
Демонолошка \\
предања \\
\\
Демонолошка \\
предања с еле- \\
ментима леген- \\
дарне приче
\end{tabular} \\
\hline
\end{tabular}




\begin{tabular}{|c|c|c|c|c|c|}
\hline 211 & $\begin{array}{l}\text { Милош Ђ. } \\
\text { Шкарић, } \\
\text { учитељ }\end{array}$ & $\begin{array}{l}\text { Села } \\
\text { Бабајић и } \\
\text { Велише- } \\
\text { вци у } \\
\text { Ваљевској } \\
\text { Колубари }\end{array}$ & $\begin{array}{l}\text { Народни живот } \\
\text { и обичаји } \\
1912 .\end{array}$ & $\begin{array}{l}\text { Празноверице, врачања и } \\
\text { бајање 211_71 } \\
\text { о Богу и другом свету 211_76 } \\
\text { Празноверице о вампирима } \\
\text { и замишљеним створовима } \\
\text { 211_76 и } 77 \\
\text { Приче } \\
\text { 4. [Мртав момак зове девојку } \\
\text { к њему, она се спасе кад легне } \\
\text { између два вола близнака] } \\
\text { 211_178 } \\
\text { Народна знања } \\
\text { Знања о човеку 211_214 } \\
\text { Знања о свету 211_214 }\end{array}$ & $\begin{array}{l}\text { Етиолошка } \\
\text { предања и еле- } \\
\text { менти легендар- } \\
\text { них прича } \\
\\
\text { Митолошко- } \\
\text { демонолошка } \\
\text { предања } \\
\text { Митолошко- } \\
\text { демонолошко } \\
\text { предање }\end{array}$ \\
\hline
\end{tabular}




\begin{tabular}{|c|c|c|c|c|c|}
\hline 221 & $\begin{array}{l}\text { Крста } \\
\text { Божовић }\end{array}$ & $\begin{array}{l}\text { Крушева- } \\
\text { чка жупа }\end{array}$ & $\begin{array}{l}\text { Народне приче } \\
\text { понајвише из } \\
\text { Жупе у округу } \\
\text { крушевачком }\end{array}$ & 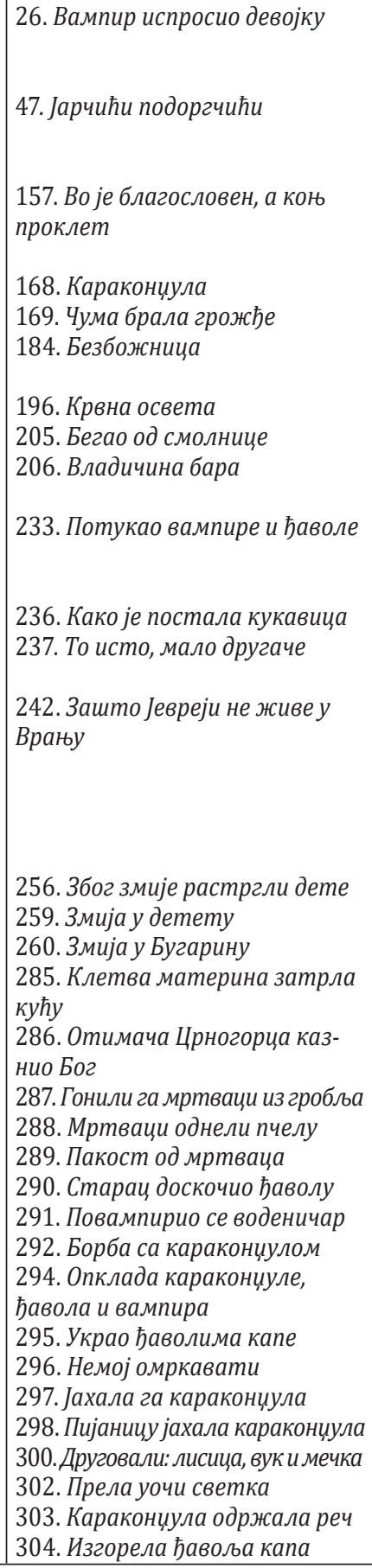 & $\begin{array}{l}\text { Демонолошко } \\
\text { предање } \\
\text { Етиолошко } \\
\text { предање } \\
\text { Етиолошко } \\
\text { предање } \\
\text { Демонолошка } \\
\text { предања } \\
\\
\text { Културно- } \\
\text { историјска } \\
\text { предања } \\
\text { Демонолошко } \\
\text { предање } \\
\text { Етиолошка } \\
\text { предања } \\
\text { Културно- } \\
\text { историјско } \\
\text { предање с еле- } \\
\text { ментима етио- } \\
\text { лошког предања } \\
\text { Више демоно- } \\
\text { лошких предања } \\
\text { и контаминација } \\
\text { различитих } \\
\text { врста }\end{array}$ \\
\hline
\end{tabular}




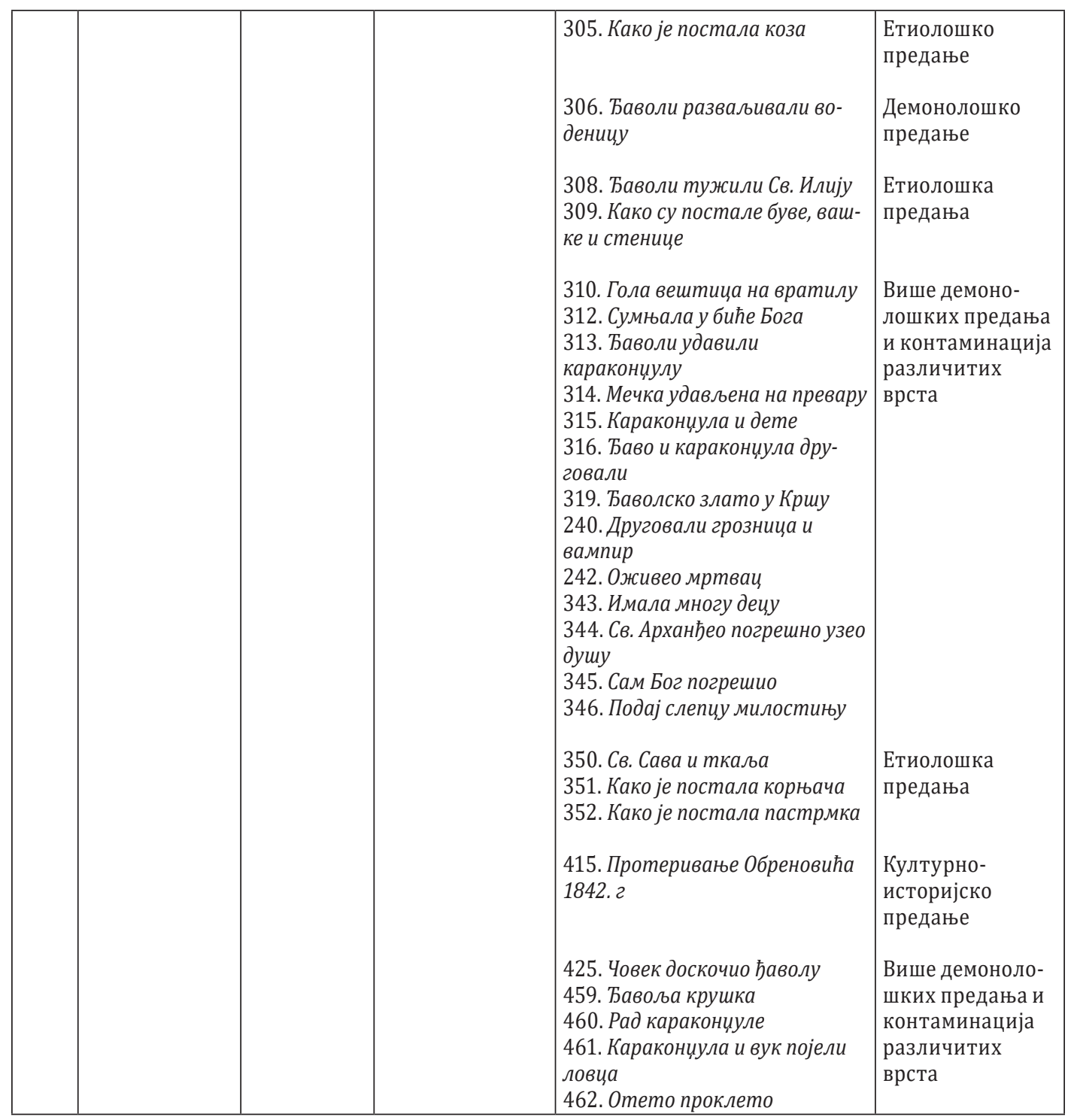




\begin{tabular}{|c|c|c|c|c|c|}
\hline 225 & $\begin{array}{l}\text { Лазар Думба } \\
\text { [Констан- } \\
\text { тин?] и други } \\
\text { скупљачи }\end{array}$ & $\begin{array}{l}\text { Јужна Стара } \\
\text { Србија } \\
\text { (Битољски } \\
\text { вилајет) }\end{array}$ & $\begin{array}{l}\text { 4. Приповетке, } \\
\text { разна веровања } \\
\text { и сујеверја } \\
1913 .\end{array}$ & $\begin{array}{l}\text { Разна веровања и сујеверја: } \\
\text { Бабини дни (или Бабини данови) } \\
\text { 225_4_13 } \\
\text { „Прости народ верујет за- } \\
\text { што на Св. Преображеније } \\
\text { Господње“ } \\
\text { Обесното теле } \\
\text { Осмак глава } \\
\text { Волко саздаен од ђавола } \\
\text { 225_4_14 } \\
\text { Грмежс т трескавица } \\
\text { Копринени буби } \\
\text { Слонзето и Месечината } \\
\text { Билот или Биволо } \\
\text { Земијава } \\
\text { Надворнешните или зли духови } \\
\text { Самовили и Вилуизите }\end{array}$ & $\begin{array}{l}\text { Етиолошка } \\
\text { и митолошко- } \\
\text { демонолошка } \\
\text { предања }\end{array}$ \\
\hline
\end{tabular}




\begin{tabular}{|c|c|c|c|c|c|}
\hline 232 & $\begin{array}{l}\text { Станоје М. } \\
\text { Мијатовић, } \\
\text { учитељь }\end{array}$ & $\begin{array}{l}\text { Моравски } \\
\text { округ }\end{array}$ & $\begin{array}{l}\text { 1. Српске народ- } \\
\text { не приче и басне } \\
\text { 2. Српске на- } \\
\text { родне приче и } \\
\text { басне (разне } \\
\text { приче, приче } \\
\text { о Краљевићу } \\
\text { Марку, о Светом } \\
\text { Сави; басне и } \\
\text { приче о лисици) } \\
1914 .\end{array}$ & 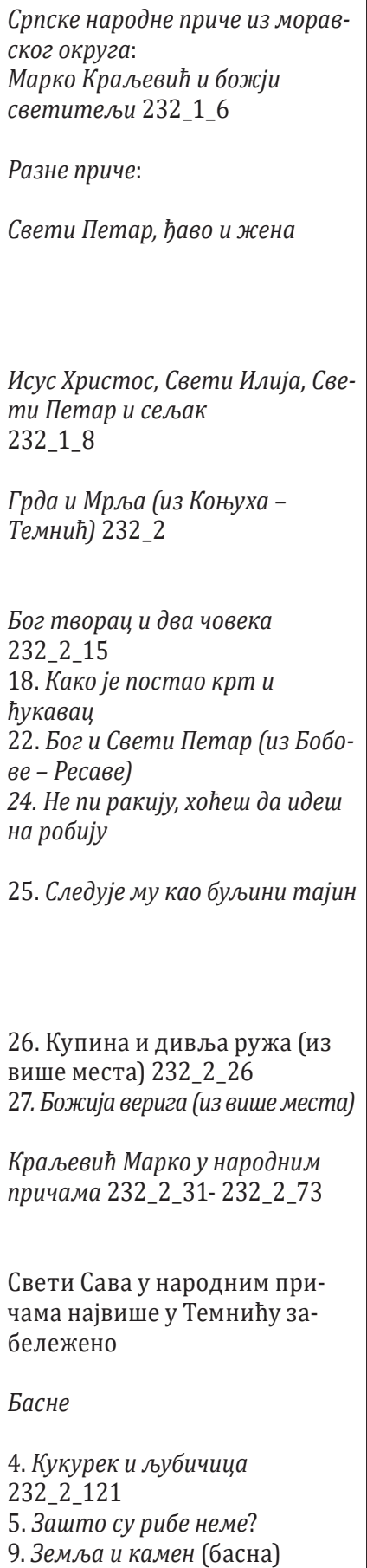 & $\begin{array}{l} \\
\text { Етиолошко } \\
\text { предање, } \\
\text { легендарна } \\
\text { прича } \\
\text { Легендарна } \\
\text { прича } \\
\\
\text { Културно- } \\
\text { историјско } \\
\text { предање } \\
\text { Етиолошка } \\
\text { предања } \\
\\
\text { Етиолошка } \\
\text { предања } \\
\text { Ера }\end{array}$ \\
\hline
\end{tabular}




\begin{tabular}{|c|c|c|c|c|c|}
\hline 234 & $\begin{array}{l}\text { Крста } \\
\text { Божовић, } \\
\text { учитељ }\end{array}$ & $\begin{array}{l}\text { Понајвише } \\
\text { из Жупе } \\
\text { крушева- } \\
\text { чке }\end{array}$ & $\begin{array}{l}\text { Народне приче } \\
1914 .\end{array}$ & $\begin{array}{l}\text { 248. Виноград цара Душана (са } \\
\text { Косова), } 141 \\
\text { 249. Смрт цара Уроша (из } \\
\text { Неродимља), } 141 \\
\text { 251. Из живота Јашар паше (са } \\
\text { Косова), } 142 \\
\text { 252. Војвода Јанић или Будић, } \\
\text { 147 } \\
\text { 253. Откуд име Косово, } 148 \\
\text { 254. Почетак отимања имања } \\
\text { манастира Грачанице (прича } \\
\text { се на Косову), 148 } \\
\text { 255. Бабушанин турска удво- } \\
\text { рица (прича из Штимља са } \\
\text { Косова), 149 } \\
\text { 256. Пренос мошти цара Уроша } \\
\text { са Косова (са Косова), } 150 \\
\text { Вампир Сава Савановић, } 178\end{array}$ & $\begin{array}{l}\text { Културно- } \\
\text { историјско } \\
\text { предање } \\
\text { Културно- } \\
\text { историјско } \\
\text { предање } \\
\text { Анегдота, еле- } \\
\text { менти културно- } \\
\text { историјског } \\
\text { предања } \\
\text { Културно- } \\
\text { историјско } \\
\text { предање } \\
\text { Етиолошко } \\
\text { предање } \\
\text { Културно- } \\
\text { историјска } \\
\text { предања }\end{array}$ \\
\hline
\end{tabular}

Приликом прегледања грађе, трудили смо се да прикупимо што потпуније податке о заступљености предања у прегледаним збиркама. ${ }^{11}$ Сакупљачи су неретко у насловима збирки наводили одговарајуће прозне врсте (нпр. народне приповетке/приче, народна предања, басне, бајке итд.), али наслови нису увек и у потпуности прецизно показивали информације о жанровским карактеристикама прикупљене грађе. Тако су предања укључивана и у оне збирке из чијих наслова не можемо закључити да ли убрајају предања (нпр. Приче Срба сељака у Левчу, E3 39), збирке чији поднаслови упућују на друге прозне врсте (Припо-

\footnotetext{
${ }^{11}$ Сложеност и обимност грађе Етнографске збирке изискивала је накнадне провере грађе у Архиву САНУ, али у току пандемије вируса Ковид-19 приступ је био онемогућен. Извесни пропусти су начињени приликом прегледања збирки Петра Мирковића (Е3 53), Сима Милеуснића (E3 74) и Михајла Ризнића (E3 83a). На постојање предања у овим збиркама указала ми је Марина Младеновић Митровић, којој дугујем захвалност и за сугестије у вези са жанровском класификацијом појединих записа.
} 
ветке, басне, бајке, Е3 157), или пак у збирке с поетичним називима (Македонске искрище, Е3 117). Ретки су скупљачи који су јасно упућивали на постојање предања (нпр. Е3 118, збирка Јанка Ђорђевића, учитеља из села Севца: Три народна предања и кратак опис села...). Назив 'предање' сакупљачи су редовно употребљавали у другачијем значењу, због чега би ослањање на нотификацију назива жанра било непоуздано.

Овај кратки осврт на називе појединих збирки говори у прилог мишљењу фолклориста да су сакупљачи предања све до средине двадесетог века или припајали ову врсту другим приповедним врстама, или су пропуштали да их идентификују као књижевну врсту. У нашој научној средини издвајање категорије предања од приповедака дуго није постојало (Милошевић-Ђорђевић 2006: 172), и она су често чинила део етнографске грађе. Истини за вољу, научници јесу могли да примете дистинктивне црте предања у односу на друге усмене врсте, али нису увек могли да их обједине у јединствену категорију. Нпр. Чајкановић у поменуту збирку Српске народне приповетке из 1927. године, поред приповедака из Етнографске збирке, уврстио је и део предања и издвојио их као скаске, легенде, веровања и примитивне приче (Чајкановић 1999: 5).

Класификација предања у рукописима из Етнографске збирке показала се као вишеструко сложен и изазован задатак како због типа збирке, тако и због начина бележења фолклорних дела у ранијим епохама (в.: Самарџија 2006; Милошевић-Ђорђевић 2013).

Део рукописа који је стигао у Академију чине етнографска и антропогеографска истраживања, изведена с циљем да се подробно проуче становништво, народни живот и обичаји неког места (села, вароши) или пак целе области (Ердељановић 1910: 4). У таквим збиркама народне умотворине и фолклор представљали су само сегмент народног живота који је требало описати и проучити. С развојем теренске етнографије у Србији у 19. веку, креирани су и специјализовани упитници који су подстицајно деловали и на теренску фолклористику, премда је њихова намена била етнографска. Ердељановићева Упутства за проучавање народа и народног живота, као и низ упутстава за проучавање села која је написао Јован Цвијић (в.: Прелић 2014), превасходно су била сачињена за антропогеографе и етнографе, па су и смернице за истраживање фолклора оскудне и дате у оквиру ширих истраживачких упутстава о проучавању села.

У упутствима која је направио Јован Ердељановић, о фолклорним врстама (песме, приче, приповетке, загонетке) говори се у одељку „Забава“, где се од сакупљача тражи да прикупи податке о заступљености народних умотворина у одређеном крају, „прибележи што већи број тамошњих приповедака и прича“, и то онако како их „народ својим 
говором прича“ (Ердељановић 1910: 32). Предања нису поменута, али је Ердељановићево упутство дошло са детаљним упутствима за испитивање празноверица, врачања и бајања (1910: 28-31).

Цвијићева упутства била су антропогеографског карактера, али се у њима налазе одељци који су могли подстицајно утицати на истраживаче да бележе предања. У више свезака Упутстава, Цвијић је тражио да истраживачи испитају локално становништво о томе да ли има „прича, којима се тумачи име села и његових крајева“ (Цвијић 1987: 28), затим да ли се нешто прича о селиштима, напуштеним локалитетима, развалинама и гробљима (1987: 31).

Теренска упутства креирана превасходно за етнографска истраживања ${ }^{12}$ један су од разлога што у појединим рукописима Етнографске збирке предања и нису издвајана од остатка етнографског текста, већ су бележена на различитим местима и могу се пронаћи у било ком одељку у оквиру описа одређеног места и народног живота. Сходно томе, и формални облик предања прилагођен је остатку етнографског текста, што отежава његову идентификацију и класификацију. На пример, у збирци Милана Матића Народ и народни живот у Крушевачкој жупи (Е3 200), предања о постанку локалног извора Краљевац и села Почековина, Мачковац и Коњуси, забележена су у делу о природним одликама области. Ова предања су интегрални део етнографског пописа села, њихов фабула је сажета, уроњена у остатак етнографског текста, због чега га је и тешко уочити и тематски класификовати.

Да су многи сакупљачи радили према етнографским упутствима сведочи и преписка коју су водили с Академијом, као и реферати чланова Академије који су износили мишљење о пристиглим збиркама Одбору. Заједно са збирком Народни живот у Бабајићу и Велимировцима у ваљевској Колубари (Е3 211), Милош Шкарић послао је и писмо Академији у коме каже да је радио „по упутствима госп. др. Ердељановића“. ${ }^{13}$ Тако, у одељку Празноверище, врачања и бајања, Шкарић следи поменута упутства и прецизно записује низ локалних веровања и предања. Мада су она по својим својствима најближа етиолошким, с одређеним елементима легендарне приче, она су заправо стилизована у форми етнографског објективног извештавања о веровањима мештана о постанку света, Богу и светитељима. Запис садржи неколико реченица које нису повезане у јединствену фабулу већ пружају одређење информације: „Сељаци држе, да су св. Илија и св. Арханђел живи на небу па им зато свечари жито не кувају.“ Даље

\footnotetext{
12 О утицају теренске етнографије на развој фолклористике у Србији в.: Петровић 2013.

${ }^{13}$ Архив САНУ, ЕЗ 211, други део.
} 
следи: „За сваку болест Бог је дао лек, за сваку болест има лековита трава, али људи не знају, која је трава од које болести лек“ (Е3 211, стр. 76). Стриктно следећи Ердељановићева упутства, Шкарић је затим донео одељак Празноверице о ванприродним и замишљеним створовима, у коме је забележио низ демонолошких предања у форми описа митских бића: „'Виле' то су лепе и младе девојке у бело обучене, које живу по високим планинама, а најрадије се задржавају по пропланцима и ту коло воде“" (Е3 211, стр. 76). На идентичан начин донети су и записи о вештици, чинилици, али и змају и дрекавцу, који садрже описе бића у форми кратког описа и народна веровања која се за њих везују.

Предања је било једноставније идентификовати и класификовати у збиркама које су садржале превасходно песничке и прозне усмене облике а не етнографску грађу, будући да су фолклорни текстови најчешће жанровски издвајани. Не улазећи у сложена питања принципа сакупљања усмене књижевности, напомињемо да су многи сакупљачи као узор имали збирке Вука Караџића, а у погледу методологије значајно место припада Тихомиру Ђорђевићу. Ђорђевић је креирао специјализоване упитнике за прикупљање фолклорне грађе, а идеју о систематичном прикупљању народних умотворина спровео је у часопису Карацић (1899-1904), за који су прилоге слали и сарадници Академије Тодор Бушетић и Станоје Мијатовић (библиографију Карацића в. у: Јовић 2016). Може се претпоставити да су се Ђорђевићеви сарадници руководили његовим инструкцијама приликом прикупљања теренске грађе и фокусирали се на бележење фолклорног текста. Ђорђевић је доприносио развоју методологије скупљања фолклора и пошто се Караиић угасио, посебно крајем двадесетих и почетком тридесетих година 20. века кад је у Гласнику Cкопског научног друштва објављивао различита питања и одговоре (в.: Глишић и Миленковић-Вуковић 2018).

Природа рукописних збирки утицала је на то која предања ће бити забележена и у којој мери. Збирке етнографског карактера доносе мањи број предања у односу на фолклорне збирке, што је и очекивано с обзиром на етнографски оријентисане сакупљаче. Сакупљачи који су се фокусирали на прикупљање народних умотворина бележили су етиолошка, културноисторијска и демонолошка предања, као и легендарне приче, док есхатолошких предања готово и да нема. Поједини сакупљачи, попут Станоја Мијатовића, Тодора Бушетића, Јанка Ђорђевића и Милоша Ивковића, бележили су етиолошка и културноисторијска предања, док демонолошка предања у потпуности изостају у овим збиркама. Разлози за то могли су бити лични афинитети сакупљача - Станоје Мијатовић и Тодор Бушетић демонолошка предања нису објављивали ни у Караиићу. 
Оријентисаност сакупљача на етиолошка и културноисторијска предања могла је бити подстакнута и тиме што је већ Стојан Новаковић наглашавао важност прикупљања „причања о местима и историји или историјским личностима“ (Годишњак 1892: 78). Уз то, у Академијином Зборнику место су могле наћи само пажљиво одабране песме и приче, то јест оно што „нађе се да вреди да се штампа“ (Годишњак 1892: 78, наш курзив), а да је претходно упоређено с Вуковим збиркама. Митолошко-демонолошка предања Вук је означио као веровања („Вјеровање ствари којијех нема“) у Животу и обичајима народа српскога, а само она најцеловитија унео је у збирку приповедака из 1853. године (Милошевић-Ђорђевић 2006: 10; в. и: МилошевићЂорђевић 1972). Сарадници Академије, нарочито они добро упознати с Вуковим радом, могли су овој групи предања посвећивати мање пажње на терену и фокусирати се на друге прозне облике. Да је митолошко-демонолошких предања било на терену, али да су она сматрана мање репрезентативним сегментом народног живота, сведочи и збирка Стевана Дучића, где су она записана у оквиру празноверица и сујеверја код Куча: „Празновјерство је Кучима урођено тако бујно, да би се могла исписати дебела књига тих празновјерних заблуда, које су у души народној од памтивјека угнјежђена“ (Е3 208/214, стр. 271).

Класификација предања из рукописа Етнографске збирке изазовна је и због саме природе овог усменог жанра. С обзиром на то да је сиже предања еластичан, да инкорпорира различите мотиве и да се често срећу контаминације, одредба да записани текст припада само једном жанру у неким случајевима није прецизна, па је она додатно нијансирана. Нпр. у збирци Тодора Бушетића (E3 39), запис Свети Јован Златоусти означен је као легендарна прича с етиолошким мотивима. У збирци Станоја Мијатовића (E3 157) налази се више записа о Марији, мајци Христовој која бежи пред гониоцима, где се етиолошки мотиви прожимају с легендарним.

Када је реч о митолошко-демонолошким предањима, питања граница жанра везана су и за комуникативну форму - меморат, фабулат и кратак опис (Fon Sidov 1987: 229-231). У поменутој збирци Стевана Дучића у поглављу Празновјерище, врачање, гатање и бајање, забележени су описи демонских бића и предања о ђаволима, лампијерима, вилама, и здухачима. Многа од ових предања представљају сложене наративне структуре у којима се описи митских бића и фабулат надовезују једни на друге, па се не може прецизно рећи где се једно предање завршава а почиње друго. У одељку о лампијеру, рецимо, налази се низ народних веровања о томе како се „човек може полампјерити“, и затим савети и упутства о томе како се ова појава открива и спречава. Уопштена веровања конкретизују се кратким, једноепизодичним 
причама у којима лампијери ноћу пресретну путника и задрже га до зоре „пјевајући му: лак полако, зор-делије / ми смо душе без костију“ (E3 208/214, стр. 290). Ради илустрације веровања, сакупљач је донео и лична сећања и приче познате мештанима које или садрже само основне податке о актерима, месту и времену догађаја, или се развијају у фабулате:

Ја знам једног Куча што је десетак година боловао, а народ је вјеровао да је узрок болести тај што га је настрцала крв, када је једног лампјера расјекао међу другим народом. [...] Кад лампијер узбијеси и осили он чини по околини штету и тад га није лако савладати. За једног таквог лампијера у Васојевићима прича се да је разбацао људима сијено и разгонио стоку по торини. Слично се прича и о Мији Р. бјелопавлићскоме лампијеру, којему је гроб пред црквом на Јеленку. Кад се пронио глас о његову лампијерству, људи одведу ноћу пастуха коња, који Мијов гроб није никако хтио прескочити, већ се трзао фрштећи у нос, док у то дотрчи однекуд лампијер и рашћера људе па насрне на два своја рођака, од којих једноме зубима преломи истргнут нож, а утолико га други сјекиром савлада, па га разбоду трновим кочевима и покрију земљом у гробу, да се већ није јављао (Е3 208/214, стр. 290).

Наведени одломак о лампијеру је сложена текстуална целина настала спајањем више фрагмената добијених од казивача, који су накнадно уобличени и приређени у једну целину. Овакав тип записа класификацију предања чини изазовном јер поставља питања везана за одређивање почетка и краја једног предања, а исто тако отвара питање односа између предања и веровања. ${ }^{14}$ Веровање је, као прозни жанр, тешко ухватљиво и креће се у „распону од језгровите констатације (да нешто треба/не треба чинити) до једноставне, сведене наративне структуре, па и једноепизодичне приче“ (Самарџија 2011: 347). Народна веровања у Етнографској збирци формулисана су као директне изјаве, јасно издвојене од остатка текста или, као што је код Дучића случај, после њих уводе се фабулати који одређено веровање потврђују или дискредитују. Проблематичност веровања односи се на његово формално постојање у усменој комуникацији, јер записи народних веровања заправо не морају представљати оно што је сакупљач на терену чуо. Фински фолклориста Лаури Хонко сматра да је народно веровање креација сакупљача и да је оно што је он чуо

\footnotetext{
${ }^{14}$ У табеларном прегледу донети су и подаци о записима веровања на оним местима где су она бележена заједно и/или у оквиру истих рубрика као и предања.
} 
од казивача заправо представља лични доживљај или искуство које је накнадно забележено у општој форми:

If, for example, the collector asks: "Are there any spirits in the barn?", then the informant normally keeps away from a generalized presentation in which he would describe what a spirit looks like and what it usually does. Instead, he begins to relate: "Last fall when I went to put more wood in the barn's stove, then (such and such happened)." In other words, he reports a memorate (Honko 1964: 10).

Ван оквира овог рада остаће разматрање односа сакупљача према меморатима који су, како се показало, изостали као комуникативни облик у коме се митолошко-демонолошка предања јављају. Напомињемо да сарадници Академије јесу бележили личне доживљаје и сведочанства из прве руке, али су она тематски одговарала културноисторијским предањима или причањима из свакодневице, нпр.:

Слично овоме вели прича и старица Ана из села Доброг Дола која сада живи у Гњилану. Но по њеном признању излази да је ово убијање попова било за време X. Нешине буне, јер она памти да је њен отац дошао из Пирота увече кући и причао овоме овако: „Па синко наши бегали од турску силу у Гургусовци и там’ се збирали, па су Турци пронашли попове кабатлије и и збесише ђи“ (Е3 207, стр. 52).

Културноисторијска предања у прегледаним збиркама су тематски мало разноврсна. Највише је оних која говоре о Марку Краљевићу, затим о Косовском боју и косовским јунацима, Грди и Мрљи (о настанку лозе Мрњавчевића), те о доласку Турака и рушењу манастира. Бележена су и локална културноисторијска предања попут оних о Стевану Синђелићу. Код културноисторијских предања запажа се уланчавање епизода. У предању Краљевић Марко као исцелитељ (Е3 117), надовезивање и уланчавање епизода твори сложену структуру. У наведеном примеру су укључена предања о постанку места, вода и извора која су на неки начин била у вези с Марком Краљевићем.

Надовезивање епизода, акумулација мотива, мотивске и жанровске контаминације, нејасне границе оквира текста предања, поједини примери књижевног уобличавања или дотеривања текстова су чиниоци који отежавају прецизну и јасну класификацију предања.

Посебно су значајни записи који сведоче да су предања забележена на терену, у непосредној контактној комуникацији: сакупљачи су их чули од казивача и записивали, или су предања доносили према сећању. Занимљив пример налазимо у збирци Дене Дебељковића, 
у Причи о Боју Косовском: „Ову ми је причу казао један старац овако: Ја сам, рече он мени, имао једну песму“ (Е3 182_1). У оба случаја, запис предања је морао проћи кроз одређену редакцију записивача. Због тога су записи предања у Етнографској збирци посебно драгоцени.

Предања у Етнографској збирци САНУ драгоцена су и са становишта изучавања терминологије којом су се служили сакупљачи на крају 19. и у првој деценији 20. века. Приче, приповетке, српске народне приповетке, етиолошке белешке, омање народне приче, српске народне приче и басне - називи су које су сакупљачи користили за своје рукописе и у њих увршћивали и предања.У поднаслову етиолошких предања Орао и врана (Е3 157) и Земља и камен (Е3 232), која је сакупио Станоје Мијатовић, стоји басна. Различиту терминологију срећемо и код митолошко-демонолошких предања која су смештана у рубрике: Празноверице, врачања и бајања или Разна веровања и сујеверја.

\section{Предности и изазови проучавања предања}

\section{у архивским записима}

На основу увида у архивске рукописе може се закључити да предања чине вредан и обиман део грађе Етнографске збирке. Њихово проучавање показује се као вишеструко изазован задатак јер отвара многобројна питања везана за жанр предања и његово постојање у усменој традицији, као и однос према другим фолклорним облицима, поготову према народном веровању.

Записи предања, настали у 19. и почетком 20. века, умногоме су зависили од вештине и памћења сакупљача. Без техничких помагала која су доступна данас (аудио и видео опреме), сарадници Академије су предања морали да записују у своје бележнице и након тога да их преписују, и тако сређене рукописе слали су Академији. Текстове су скупљачи редиговали и стилизовали у складу с наменом рукописа, па се они разликују од савремених теренских записа предања који су погоднији за изучавање перформативних аспеката и индивидуалног стила казивача. С друге стране, записи у рукописима из Етнографске збирке отварају више могућности за дијахронијско проучавање предања. Рукописне збирке показују како су скупљачи крајем 19. века посматрали различите врсте предања и како су их бележили. Имајући то у виду, темељно проучавање предања у рукописима из Етнографске збирке Архива САНУ је неопходан научни корак који би допринео целовитијој слици о предањима, њиховој идентификацији и учвршћивању њиховог места у српској фолклористици. 


\section{Библиографија}

Гароња-Радованац, С. (2012). Дигитализација Етнографске збирке архива САНУ у проучавању и модерном презентовању српске фолклористике, у: А. Вранеш, Љ. Марковић, Г. Александер (ур.), Дигитализација културне и научне баштине, књ. 1. Ур. Београд: Филолошки факултет, Народна библиотека Србије; Вичита: Универзитет Емпориа, 199-224.

Глишић, С. и Миленковић-Вуковић, Б. (2018). Тихомир Р. Ђорђевић - 150 година од рођења (виртуелна изложба). Универзитетска библиотека „Светозар Марковић, Београд. http://www.unilib.rs/izlozbe/tihomir_djordjevic/index.html (19. 5. 2021).

Годишњак (1892). Годишњак Српске краљевске академије, VI. Београд: СКА.

Годишњак (1895). Годишњак Српске краљевске академије, IX. Београд: СКА.

Годишњак (1898). Годишњак Српске краљевске академије, XII. Београд: СКА.

Ђорђевић, Б. (2010). Архивистички појмовник. Београд: Филолошки факултет.

Ђорђевић, Д. (1988). Српске народне приповетке и предања из лесковачке области. Прир. Н. Милошевић-Ђорђевић. Београд: САНУ.

Ђорђевић, Т. (1984). Наш народни живот I-IV. Прир. Н. Љубинковић. Београд: Просвета.

Ердељановић, J. (1910). Упутства за испитивање народа и народног живота. Српски етнографски зборник, књ. 16. Београд: СКА.

Јовић, Д. (2016). Библиографија часописа Караџић. Фолклористика 1/1, 149-224.

Марковић, С. (2004). Приповетке и предања из Левча. Крагујевац: Центар за научна испитивања САНУ и Универзитета у Крагујевцу, Београд: Чигоја штампа.

Милошевић-Ђорђевић, Н. (1972). Вуково схватање народних предања (Неколика запажања). Научни састанак слависта у Вукове дане, 2, 121-125.

Милошевић-Ђорђевић, Н. (2006). Од бајке до изреке, Београд: Друштво за српски језик и књижевност Србије.

Милошевић-Ђорђевић, Н. (2013). Путеви идентификације предања у развоју српске фолклористике, у: 3. Карановић и Ј. Јокић (ур.), Савремена српска фолклористика І. Нови Сад: Универзитет у Новом Саду, Филозофски факултет, 206-211.

Младеновић, Ж. (2005). На изворима народне песме. Београд: Чигоја штампа.

Палавестра, В. (2003). Хисторијска усмена предања из Босне и Херцеговине. Београд: Српски генеалошки центар.

Петровић, С. (2013). Теренско истраживање фолклора у Србији: кратак осврт, савремено стање и перспективе, у: 3. Карановић и Ј. Јокић (ур.), Савремена српска фолклористика І. Нови Сад: Универзитет у Новом Саду, Филозофски факултет, 222-232.

Прелић, М. (2014). Јован Цвијић и прве деценије формирања и институционализовање етнологије као науке у Србији. Гласник Етнографског инстиmyта CAHY, 62(2), 83-97. DOI: 10.2298/GEI1402083P

Самарџија, С (2006). Од казивања до збирке народних прича. Прилог проучавању историје народне књижевности. Бања Лука: Књижевна задруга.

Самарџија, С. (2011). Облици усмене прозе. Београд: Службени гласник.

Цвијић, J. (1987). Антропогеографски и етнографски списи. Сабрана дела. Београд: САНУ, НИРО „Књижевне новине“, Завод за уџбенике и наставна средства. 
Чајкановић, В. (1999). Српске народне приповетке. Београд: Гутенбергова галаксија.

Bošković-Stulli, M. (1968). Narodna predaja - Volkssage - kamen spoticanja u podjeli vrsta usmene proze. Radovi Zavoda za slavensku filologiju, 10, 27-40.

Fon Sidov, K. (1987). Kategorije proznog narodnog pesništva. Polja, 340, 229-231.

Honko, L. (1964). Memorates and the Study of Folk Beliefs. Journal of the Folklore Institute, 1(1/2), 5-19. DOI: 10.2307/3814027 (19. 5. 2021).

Karanović, Z. (1989). Zakopano blago - Život i priča. Novi Sad: Bratstvo-jedinstvo, Institut za jugoslovenske književnosti i opštu književnost Filozofskog fakulteta u Novom Sadu.

Milošević-Đorđević, N. (2012). A survey of approaches to legends in Serbian scholarship. In: Z. Karanović, W. de Blécourt (eds.), Belief Narrative Genres. Novi Sad: ISFNR-Univerzitet u Novom Sadu, 42-50.

\title{
Records of Legends in the Ethnographic Collection of the Serbian Academy of Sciences and Arts (1886-1914)
}

\author{
Danica Jović
}

\section{Summary}

The paper discusses legends in the Ethnographic Collection of the Serbian Academy of Sciences and Arts (SASA) between 1886 and 1914. A short review is given of establishing the Ethnographic Board and its initiative for collecting and publishing folklore material. The aim of this paper is to identify the manuscripts containing legends, as well as their systematization, following Budapest classification of legends. The research shows that certain groups of legends are at the same time part of collections of ethnographic material as well as of folktale collections. Legends were differently perceived and recorded by the collectors. The ethnographically oriented collectors focused on legends' explanatory function and observed them as part of folk religion. The collectors focused on recording folk literature, recorded legends together with other folklore genres, but rarely made a distinction between legends and folktales.

Key words: the Ethnographic Collection of SASA, Serbian folk legends, Budapest classification, ethnographic material.

МА Даница Јовић

Докторанткиња на Филолошком факултету

Универзитета у Београду

Примљено: 12. 3. 2021.

Е-пошта: danicajjovic@gmail.com

Прихваћено: 10. 6. 2021. 